\title{
PHYSICOCHEMICAL PROPERTIES OF WATER-SOLUBLE CONTRAST MEDIA
}

The most important physicochemical properties of water-soluble, iodinated CM are their solubility, the viscosity and osmolality of the solutions, the lipophilic or hydrophilic properties of the iodine-containing molecule, and the electrical charge (table 4). In practice, these properties have the following significance:

\section{Water solubility}

Very good water solubility is a prerequisite for the production of highly concentrated, radiopaque CM. As with sugars or peptides, the solubility of nonionic $\mathrm{CM}$ is mediated by hydrophilic groups $(-\mathrm{OH}$, -CONH-). Some commercially available CM can crystallize at low temperature and must be dissolved again before use by warming up.

\begin{tabular}{ll} 
Property & Significance \\
Solubility & $\begin{array}{l}\text { Maximum possible concentration; where applicable, need to dissolve } \\
\text { crystals in warmth before use }\end{array}$ \\
\hline Viscosity & $\begin{array}{l}\text { Rate of injection; infusion. Highly viscous solutions can impair } \\
\text { microcirculation in selective angiography }\end{array}$ \\
\hline Osmolality & $\begin{array}{l}\text { Pain in some angiographic indications; endothelial damage; arachnoiditis(?) } \\
\text { in myelography; bradycardia in cardioangiography; hypervolemia after very } \\
\text { rapid i.v. injection at high dose; diueresis }\end{array}$ \\
\hline $\begin{array}{l}\text { Lipophilicity, absence } \\
\text { of hydrophilia } \\
\text { (of ionic CM) }\end{array}$ & $\begin{array}{l}\text { General reactions (nausea, vomiting, allergy-like reactions) more frequent, } \\
\text { particularly at high dose and on rapid injection; protein binding, prevention } \\
\text { of glomerular filtration; tubular secretion; biliary elimination; permeation } \\
\text { through cell membranes, enteral absorption }\end{array}$ \\
\hline Electric charge & Improvement of solubility; increases the hydrophilia; epileptgenicity \\
\hline
\end{tabular}

Table 4. The most important physicochemical properties of water-soluble, iodinated CM 


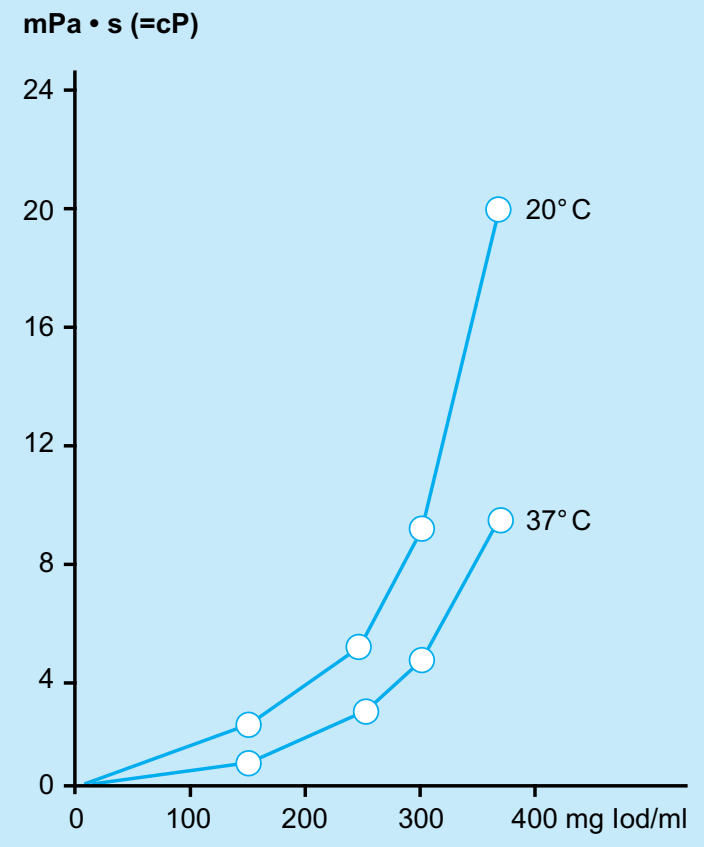

Fig. 8. Viscosity of Ultravist in relation to its concentration

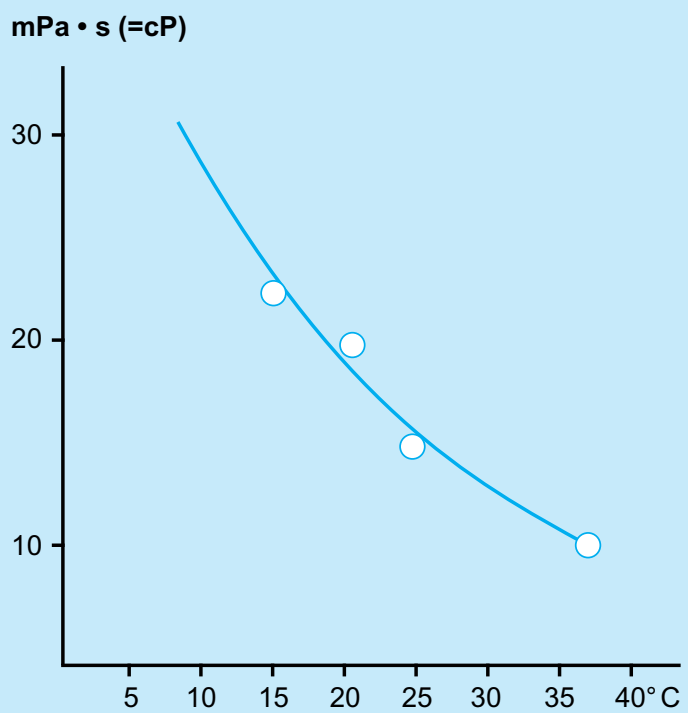

Fig. 9. Viscosity of Ultravist-370 in relation to temperature

\section{Viscosity/Temperature}

Viscosity is a measure of the flow properties of a solution and is expressed in millipascal second (identical with the older unit centipoise). It strongly increases with increasing concentration and falling temperature (figs. 8, 9). The viscosity of the different $\mathrm{CM}$ is different at the same iodine concentration and same temperature (table 2).

This clearly affects the maximum injection speed, if, e.g., narrow catheters or thin needles are used or if the injection of greater volumes is necessary. Injection speed can be given in mg iodine/ second, as this is the parameter which determines contrast (table 5).

\section{Osmolality}

\section{Osmotic pressure}

The osmotic pressure of a solution can be calculated in two different units, osmolarity and osmolality. The osmolarity is the concentration of osmotically active particles in relation to the volume of a solution. In the case of nonelectrolytes, it is identical to molarity; for dissociated substances $\hat{=}$ molarity times the number of ions in one mole; given as osmo/L solution.

\begin{tabular}{lc} 
& mg lod/s \\
Ultravist-300 & 2027 \\
\hline lopamidol-300 & 1974 \\
\hline Ominipaque-300 & 1753 \\
\hline Ominipaque-350 & 1477 \\
\hline
\end{tabular}

Table 5. Maximum possible injection speed through an $5 \mathrm{~F}$ headhunter catheter, contrast medium temperature of $37^{\circ} \mathrm{C} ; n=20$ per contrast medium [17] 
Osmolality describes the concentration of solute per $\mathrm{kg}$ of water. The osmolality of $\mathrm{CM}$ solutions is expressed in milliosmol/kg water, in megapascal or in atmospheres $(1,000 \mathrm{mosm} / \mathrm{kg}=2.58 \mathrm{MPa}=25.5 \mathrm{at})$. It is approximately proportional to the number of freely mobile particles (molecules, ions) per kg water. The osmolality of $\mathrm{CM}$ is dependent very much on the concentration and only slightly on the temperature (fig. 10). Different CM can display greatly diverging osmolalities at the same concentration of iodine.

\section{Hydrophilia/Lipophilia}

The lipophilia of iodine-containing CM acids or of nonionic CM is calculated from their distribution between a solvent (octanol, butanol) which is not miscible with water and an aqueous buffer with a $\mathrm{pH}$ value (distribution coefficient) close to that of blood or tissues (fig. 11). The electrical charge (acid group) and the oxygen and nitrogen atoms in the side chains reduce the lipophilia of tri-iodobenzene, while methyl groups in the side chains increase it. CM for urography, angiography, CT and myelography should display as little lipophilia as possible.

For ionic contrast media, a correlation was found between lipophilia and certain types of side-effects. This correlation was even more obvious when the degree of binding of the contrast media to plasma proteins was measured rather than lipophilia.

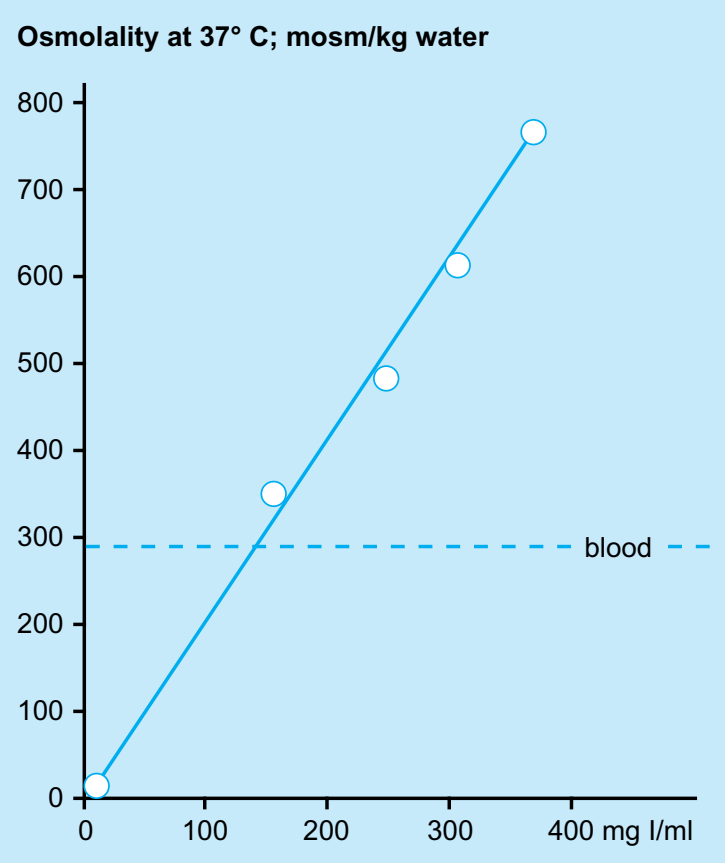

Fig. 10. Relationship of the osmolality of Ultravist to the CM concentration

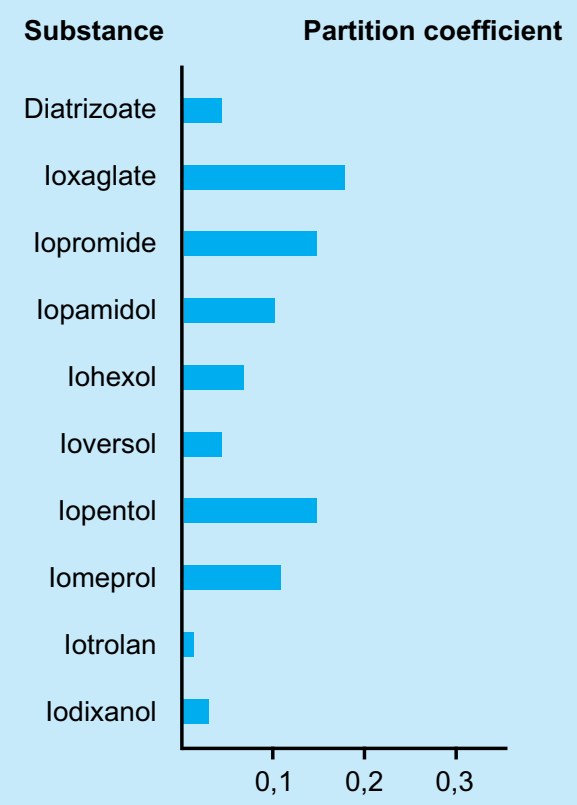

Fig. 11. Partition coefficients of different $\mathrm{CM}$ between n-butanol and buffer with $\mathrm{pH} 7.6$ 
Nonionic contrast media are generally very hydrophilic. Their binding to plasma proteins is minor and does not correlate with lipophilia (table 2). The latter is measured as a distribution coefficient (fig. 11). It would seem that hydrogen bonds and other factors play a larger role regarding protein binding and tolerance. Undoubtedly, the tolerance of these substances is also influenced by factors which cannot be measured physicochemically. Cholegraphic CM and particularly the oral ones must be very much more lipophilic to fulfill their purpose.

\section{Electrical charge}

Originally, water-soluble CM were salts of iodinated organic acids. A contrast-producing iodinated anion in solution carries one or two negative charges, whereas a non-contrast-producing cation (e.g., sodium, meglumine) carries one positive electrical charge. Although cations do not directly enhance radiographic imaging, they are essential for improving the solubility of iodinated acids and for attaining physiological $\mathrm{pH}$ values. Only acidic $\mathrm{CM}$ are effective as biliary contrast media, since only they are eliminated quickly enough by means of a hepatic anion transport mechanism.

For all other indications, the new electrically neutral, nonionic $\mathrm{CM}$ have proven more suitable: the cations of CM salts unnecessarily increase the osmolality of the solutions and cause additional, generally undesired effects. The CM ions disturb the electrical potential on cell membranes. Electrical charge is the cause of a host of unwanted interactions of $\mathrm{CM}$ with the organism. 


\section{Specific gravity/Density}

Concentrated CM solutions are of considerably higher density than water (table 6). The higher density is almost exclusively related to the heavy element iodine. In association with viscosity, the density of CM complicates their miscibility with physiological $\mathrm{NaCl}$ solution or blood.

\section{Others}

Several other properties of X-ray contrast media are also of substantial significance. Binding to biomolecules can be mediated not only by the electrical charge and lipophilic groups but also by hydrogen bonds (fig. 12). Hydrogen bonds are responsible for the spatial arrangement of polypeptide chains (folding) and nucleic acids (helix). In many cases they determine the functionality of the macromolecule. The association of X-ray contrast medium molecules with each other in concentrated solution must also be due primarily to hydrogen bonds.

Further relevant properties include the high density (the high specific gravity) of concentrated contrast medium solutions, which hinders the mixing of aqueous solutions with blood, the (minimal) buffering capacity, which ensures rapid assimilation of the contrast medium $\mathrm{pH}$ to blood $\mathrm{pH}$, and the powerful absorption of UV light, which is responsible for the light sensitivity of iodinated X-ray contrast media.

\begin{tabular}{|c|c|c|c|}
\hline & \multirow[t]{2}{*}{$\mathrm{mg} \mathrm{lod} / \mathrm{ml}$} & \multicolumn{2}{|c|}{ Densitiy kg/L } \\
\hline & & $20^{\circ} \mathrm{C}$ & $37^{\circ} \mathrm{C}$ \\
\hline Water & & 0.998 & 0.993 \\
\hline \multirow[t]{4}{*}{ Ultravist } & 150 & 1.154 & 1.158 \\
\hline & 240 & 1.263 & 1.255 \\
\hline & 300 & 1.328 & \\
\hline & 370 & 1.409 & 1.399 \\
\hline \multirow[t]{3}{*}{ Iopamiron } & 200 & 1.223 & 1.216 \\
\hline & 300 & 1.332 & \\
\hline & 370 & 1.415 & 1.405 \\
\hline \multirow[t]{3}{*}{ Omnipaque } & 240 & 1.418 & 1.264 \\
\hline & 300 & 1.343 & \\
\hline & 350 & 1.457 & 1.391 \\
\hline \multirow[t]{2}{*}{ Isovist } & 240 & 1.285 & 1.269 \\
\hline & 300 & 1.353 & 1.344 \\
\hline Iopentol & 300 & 1.332 & \\
\hline \multirow[t]{2}{*}{ loversol } & 300 & 1.348 & \\
\hline & 320 & 1.370 & \\
\hline
\end{tabular}

Table 6. Density of different nonionic X-ray contrast agents at $20^{\circ}$ and $37^{\circ} \mathrm{C}$.

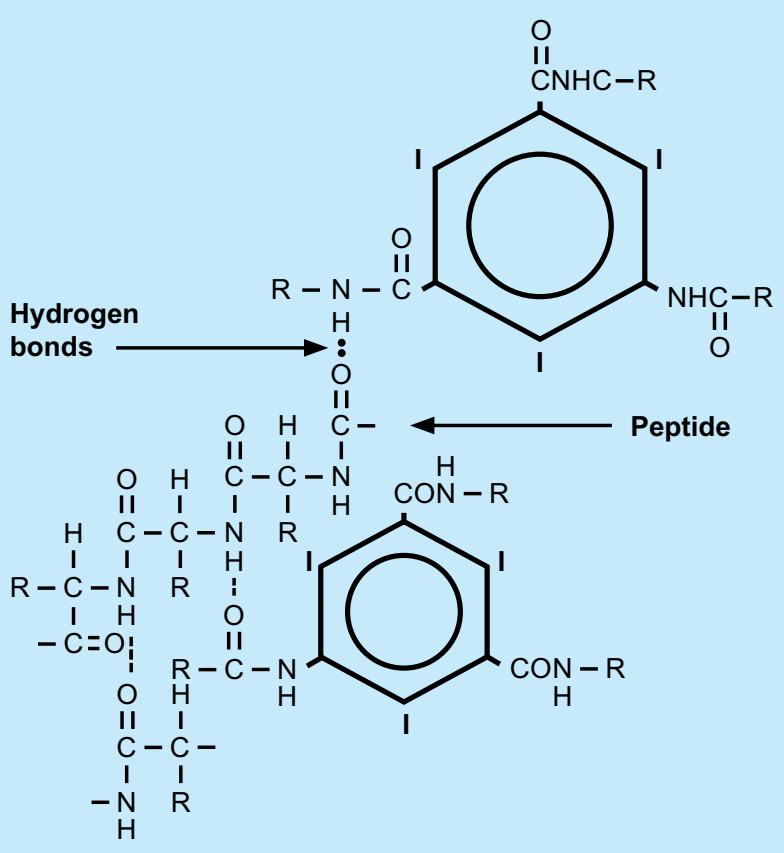

Fig. 12. Examples of possible hydrogen bonds (--) between polypeptides and CM 
Open Access This chapter is licensed under the terms of the Creative Commons Attribution 4.0 International License (http://creativecommons.org/licenses/by/4.0/), which permits use, sharing, adaptation, distribution and reproduction in any medium or format, as long as you give appropriate credit to the original author(s) and the source, provide a link to the Creative Commons license and indicate if changes were made.

The images or other third party material in this chapter are included in the chapter's Creative Commons license, unless indicated otherwise in a credit line to the material. If material is not included in the chapter's Creative Commons license and your intended use is not permitted by statutory regulation or exceeds the permitted use, you will need to obtain permission directly from the copyright holder. 